\title{
THE EFFECTS OF 1-HYDRAZINOPHTHALAZINE ON CEREBRAL BLOOD FLOW, VASCULAR RESISTANCE, OXYGEN UPTAKE AND JUGULAR OXYGEN TENSION IN HYPERTENSIVE SUBJECTS ${ }^{1}$
}

\author{
BY JOSEPH H. HAFKENSCHIEL AND CARL K. FRIEDLAND, WITH THE ASSISTANCE OF \\ JOHN YOBBAGY, HENRIETTA BRANDT, JANET MERRILL AND \\ NELLY K. LINCOLN
}

\author{
(From the Edward B. Robinette Foundation, Medical Clinic, Hospital of the University of \\ Pennsylvania and the Department of Pharmacology, School of Medicine, University \\ of Pennsylvania, Philadelphia, Pennsylvania)
}

(Submitted for publication August 25, 1952 ; accepted April 4, 1953)

1-hydrazinophthalazine ("Apresoline") has been shown to lower the blood pressure and augment the renal blood flow in certain hypertensive patients $(1,2)$. Although the drug induces vasodilatation, its exact mechanism of action requires further study. Some evidence suggests that it may suppress the sympathetic vasoconstrictor reflexes which cause the "overshoot" in arterial pressure following the Valsalva maneuver (3). Also it appears to have the capacity of inhibiting pressor substances of either renal (4) or cerebral (5) origin.

The present study was undertaken in order to measure the effect of this drug, given intramuscularly, on cerebral blood flow, cerebral vascular resistance, cerebral oxygen uptake and jugular venous oxygen tension of patients with essential hypertension. For comparison, other patients were given a placebo. The effects of "Apresoline" have been compared with the changes observed after the placebo and during the hypotension induced by differential spinal sympathetic block (6), $20^{\circ}$ head-up tilt (7), dihydroergocornine (8), protoveratrine (9), and sympathectomy (10).

\section{METHODS}

1. Choice of subjects: Seven patients with essential hypertension were selected from the medical and surgical wards of the Hospital of the University of Pennsylvania for the "Apresoline" study. Two patients were in the Group I life expectancy classification of Smithwick (11), three were in Group II and two were in Group IV (poorest prognosis).

1 This investigation is being supported in part by research grants from the National Heart Institute, U. S. Public Health Service (H-361), and the Ciba Pharmaceutical Products, Inc.
The placebo injection study group consisted of the following six patients : one in Group I, three in Group II and two in Group IV. Five additional patients were studied after subtotal adrenalectomy (12) (approximately 88-98 per cent) before and after the placebo. The preadrenalectomy grouping of these patients with severe hypertension and vascular complications was: one in Group II and four in Group IV. They were selected at random without regard to their postoperative blood pressure level. All patients were ambulatory and required cortisone or cortisone and desoxycorticosterone at the time of the initial postadrenalectomy study. One patient, I. B. (Table II), was tested 3 and 12 months after operation. These patients were tested to see whether patients with adrenalectomy responded differently after the placebo injection as to mean arterial pressure, cerebral blood flow and oxygen consumption and jugular venous oxygen tension. These patients are shown below the heavy line in Table II.

2. Technique of study: Cerebral blood flow and oxygen consumption were determined in the supine position by the nitrous oxide method (13). Mean femoral arterial pressure was measured through an indwelling femoral arterial needle. Analyses of blood gases were made by methods reported previously $(13,14)$. Hydrogen ion concentration of arterial and venous blood was measured anaerobically at room temperature and corrected to $37^{\circ}$ C. (15). Hemoglobin concentration was measured with the Evelyn colorimeter and the oxygen capacity calculated therefrom. The derived jugular venous oxygen saturation and jugular venous blood $\mathrm{pH}$ allowed an estimation of jugular venous oxygen tension from the data of Dill $(6,16)$. This estimation is assumed to vary directly with cerebral oxygen tension (17). The drug was injected intramuscularly immediately upon completion of the control observations.

3. Dosage of drug and placebo: The dosage of 1-hydrazinophthalazine ${ }^{2}$ varied from $0.14 \mathrm{mgm}$. to $0.36 \mathrm{mgm}$. per kilogram of bodyweight (total dose 10 to $20 \mathrm{mgms}$.). Four patients received $14 \mathrm{mgms}$. or less. The second

2 Generous supplies were made available by F. L. Mohr, M.D., of Ciba Pharmaceutical Products, Inc., Summit. New Jersey. 
cerebral blood flow measurement was made between 50 and 70 minutes after the intramuscular injection. By this time the arterial pressure had become stabilized at its lowest level or had begun to rise.

The patients in the placebo experiment were given 1.0 cc. of 0.9 per cent $\mathrm{NaCl}$ solution intravenously after the control study. The second study of the cerebral circulation was made 60 minutes later. The patients were told that a substance had been given which would lead to a more relaxed feeling. The apparent state of nervous tension of the subject during the initial and subsequent study was estimated.

\section{RESULTS}

Tables I and II contain the results obtained in each test. The initial mean values, mean changes and standard deviations of each group are summarized in Table III. The reductions in mean arterial pressure, cerebral vascular resistance and arterial carbon dioxide tension induced by 1-hydrazinophthalazine were the only significant changes $(\mathrm{p}<0.02)$.

TABLE I

Effects of intramuscular 1-hydrazinophthalasine on cerebral circulation and oxygen metabolism of patients with essential hypertension

\begin{tabular}{|c|c|c|c|c|c|c|c|c|c|c|c|c|c|c|c|c|c|c|c|c|c|c|c|}
\hline \multirow{4}{*}{ Patient } & \multirow{4}{*}{ Sex } & \multirow{4}{*}{ Age } & \multirow{4}{*}{$\begin{array}{l}\text { Smith- } \\
\text { wick } \\
\text { group }\end{array}$} & \multicolumn{8}{|c|}{ Carbon dioxide } & \multirow{2}{*}{\multicolumn{4}{|c|}{ Blood pH $37^{\circ} \mathrm{C}$. }} & \multicolumn{8}{|c|}{ Oxygen } \\
\hline & & & & \multicolumn{4}{|c|}{$\begin{array}{c}\text { Content } \\
\text { oolumes \% }\end{array}$} & \multicolumn{4}{|c|}{$\begin{array}{l}\text { Tension } \\
\text { mm. Hg }\end{array}$} & & & & & \multicolumn{4}{|c|}{$\underset{\text { volumes \% }}{\text { Content }}$} & \multirow{2}{*}{\multicolumn{2}{|c|}{$\frac{\begin{array}{c}\text { Tension } \\
m m . H g\end{array}}{\text { Venous }}$}} & \multirow{2}{*}{\multicolumn{2}{|c|}{$\begin{array}{c}\begin{array}{c}\text { Saturation } \\
\% \text { oxy } \mathbf{H b}\end{array} \\
\text { Venous }\end{array}$}} \\
\hline & & & & \multicolumn{2}{|c|}{ Arterial } & \multicolumn{2}{|c|}{ Venous } & \multicolumn{2}{|c|}{ Arterial } & \multicolumn{2}{|c|}{ Venous } & \multicolumn{2}{|c|}{ Arterial } & \multicolumn{2}{|c|}{ Venous } & \multicolumn{2}{|c|}{ Arterial } & \multicolumn{2}{|c|}{ Venous } & & & & \\
\hline & & & & B $\ddagger$ & As & B & $\mathbf{A}$ & B & $\mathbf{A}$ & B & $\mathbf{A}$ & B & $\mathbf{A}$ & B & $\mathbf{A}$ & B & $\mathbf{A}$ & B & $\mathbf{A}$ & B & $\mathbf{A}$ & B & $\mathbf{A}$ \\
\hline H. R. & F & 21 & I & 56.9 & 50.8 & 65.8 & 55.9 & 41 & 34 & 52 & 37 & 7.50 & 7.57 & 7.42 & 7.52 & 21.1 & 21.5 & 12.7 & 17.5 & 30 & 38 & 61 & 80 \\
\hline A. C. & F & 50 & I & 53.2 & 48.6 & 58.9 & 50.2 & 45 & 36 & 57 & 39 & 7.41 & 7.48 & 7.33 & 7.43 & 18.7 & 18.6 & 12.5 & 11.8 & 34 & 29 & 61 & 57 \\
\hline N. M. & F & 52 & II & 47.7 & 45.6 & 54.3 & 50.5 & 43 & 37 & 54 & 42 & 7.36 & 7.43 & 7.43 & 7.39 & 15.7 & 15.7 & 10.5 & 11.6 & 30 & 31 & 60 & 64 \\
\hline \multirow{2}{*}{ D. F. } & \multirow{2}{*}{$\mathbf{M}$} & \multirow{2}{*}{30} & II & 46.6 & 44.9 & 51.3 & 49.6 & 40 & 39 & 48 & 42 & 7.40 & 7.40 & 7.43 & 7.35 & 18.2 & 18.4 & 12.1 & 12.5 & 34 & 35 & 61 & 63 \\
\hline & & & II & 47.5 & 45.3 & 54.0 & 50.5 & 45 & 42 & 48 & 50 & 7.33 & 7.36 & 7.29 & 7.31 & 19.0 & 19.6 & 12.7 & 13.6 & 38 & 38 & 66 & 66 \\
\hline H. C. & $\mathbf{M}$ & 44 & II & 53.2 & 49.7 & 58.7 & 53.3 & 47 & 41 & 60 & 47 & 7.36 & 7.42 & 7.30 & 7.37 & 18.5 & 18.3 & 12.4 & $\mid 12.9$ & 41 & 41 & 70 & 74 \\
\hline A. $\mathbf{M}$. & F & 39 & IV & 59.2 & 55.6 & 65.3 & 62.0 & 49 & 42 & 64 & 56 & 7.40 & 7.44 & 7.31 & 7.35 & 15.7 & 14.8 & 9.0 & 8.4 & & & & \\
\hline v. J. & F & 47 & IV & $\overline{55.3}$ & $\overline{52.4}$ & $\overline{59.6}$ & $\overline{57.0}$ & 41 & 35 & 50 & 41 & 7.46 & 7.52 & 7.39 & 7.46 & 17.9 & $\overline{17.7}$ & $\overline{11.8}$ & 12.0 & 34 & 31 & 64 & 65 \\
\hline
\end{tabular}

TABLE I-Continued

\begin{tabular}{|c|c|c|c|c|c|c|c|c|c|c|c|c|c|c|c|c|c|c|c|}
\hline \multirow{3}{*}{ Patient } & \multirow{3}{*}{ Sex } & \multirow{3}{*}{ Age } & \multirow{3}{*}{$\begin{array}{l}\text { Smith- } \\
\text { wick } \\
\text { group }\end{array}$} & \multicolumn{10}{|c|}{ Cerebral } & \multirow{2}{*}{\multicolumn{2}{|c|}{$\begin{array}{l}\text { Pulse } \\
\text { rate } \\
\text { per } \\
\text { minute }\end{array}$}} & \multirow{2}{*}{\multicolumn{2}{|c|}{$\begin{array}{c}\text { Respiratory } \\
\text { rate } \\
\text { per } \\
\text { minute }\end{array}$}} & \multicolumn{2}{|c|}{ Dosage } \\
\hline & & & & \multicolumn{2}{|c|}{$\begin{array}{l}\text { Blood } \\
\text { flow (X)* }\end{array}$} & \multicolumn{2}{|c|}{$\begin{array}{c}\text { Oxygen } \\
\text { uptake (X) }\end{array}$} & \multicolumn{2}{|c|}{$\underset{\text { resistancet }}{\text { Vascular }}$} & \multicolumn{2}{|c|}{$\begin{array}{c}\text { Respiratory } \\
\text { quotient }\end{array}$} & \multicolumn{2}{|c|}{ 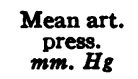 } & & & & & \multirow{2}{*}{$\underset{\text { total }}{\text { Mgm. }}$} & \multirow{2}{*}{$\begin{array}{c}\text { Mgm } \\
\text { per } \\
\text { kilo }\end{array}$} \\
\hline & & & & B & $\mathbf{A}$ & B & $\mathbf{A}$ & B & $\mathbf{A}$ & B & $\mathbf{A}$ & B & $\mathbf{A}$ & B & $\mathbf{A}$ & B & $\mathbf{A}$ & & \\
\hline H. $\mathbf{R}$. & F & 21 & I & 39 & 47 & 3.3 & 1.9 & 4.0 & 3.0 & 1.06 & 1.28 & 155 & 141 & 90 & 105 & 18 & 19 & 10 & 0.18 \\
\hline A. C. & F & 50 & I & 69 & 52 & 4.3 & 3.6 & 2.0 & 2.0 & 0.92 & 0.24 & 137 & 106 & 78 & 84 & 16 & 20 & 12 & 0.20 \\
\hline N. M. & F & 52 & II & 55 & 79 & 2.9 & 3.9 & 2.7 & 1.3 & 1.27 & 1.00 & 146 & 103 & 66 & 76 & 14 & 14 & 14 & 0.20 \\
\hline \multirow{2}{*}{ D. F. } & \multirow{2}{*}{$\mathbf{M}$} & \multirow{2}{*}{30} & II & 49 & 67 & 3.0 & 4.0 & 2.3 & 1.6 & 0.77 & 0.80 & 113 & 108 & 72 & 69 & 12 & 14 & 10 & 0.14 \\
\hline & & & II & 77 & 65 & 4.9 & 4.0 & 1.9 & 2.0 & 1.03 & 0.85 & 147 & 131 & 72 & 76 & 16 & 19 & 17 & 0.24 \\
\hline H. C. & $\mathbf{M}$ & 44 & II & 40 & 42 & 2.7 & 2.2 & 3.5 & 2.6 & 0.90 & 0.67 & 140 & 108 & 64 & 64 & 16 & 20 & 13 & 0.14 \\
\hline A. $\mathbf{M}$. & $F$ & 39 & IV & 70 & 61 & 4.7 & 3.9 & 2.1 & 1.3 & 0.91 & 1.00 & 148 & 81 & 87 & 85 & 16 & 16 & 20 & 0.36 \\
\hline V. J. & F & 47 & IV & 45 & 42 & 2.8 & 2.4 & 3.6 & 3.0 & 0.70 & 0.81 & 162 & 127 & 90 & 114 & 28 & 28 & 18 & 0.25 \\
\hline
\end{tabular}

(X) cc. per 100 grams per min.

t Cerebral vascular resistance is mean arterial pressure divided by cerebral blood flow expressed as $\mathrm{mm}$. $\mathrm{Hg}$ per cc. blood per 100 grams brain per minute.

¥ B denotes study made before drug injection.

A denotes study made after drug injection. 
TABLE II

Effects of intravenous placebo on cerebral circulation and oxygen metabolism of patients with essential hypertension

\begin{tabular}{|c|c|c|c|c|c|c|c|c|c|c|c|c|c|c|c|c|c|c|c|c|c|c|c|}
\hline \multirow{4}{*}{ Patient } & \multirow{4}{*}{ Sex } & \multirow{4}{*}{ Age } & \multirow{4}{*}{$\begin{array}{l}\text { Smith- } \\
\text { wick } \\
\text { group }\end{array}$} & \multicolumn{8}{|c|}{ Carbon dioxide } & \multirow{2}{*}{\multicolumn{4}{|c|}{ Blood $\mathrm{pH} 37^{\circ} \mathrm{C}$. }} & \multicolumn{8}{|c|}{ Oxygen } \\
\hline & & & & \multicolumn{4}{|c|}{$\begin{array}{c}\text { Content } \\
\text { volumes \% }\end{array}$} & \multicolumn{4}{|c|}{$\begin{array}{l}\text { Tension } \\
\text { mm. } B_{8}\end{array}$} & & & & & \multicolumn{4}{|c|}{$\underset{\text { columes \% }}{\text { Content }}$} & \multirow{2}{*}{\multicolumn{2}{|c|}{$\begin{array}{c}\begin{array}{c}\text { Tension } \\
\text { mm. } \boldsymbol{H}_{\mathrm{g}}\end{array} \\
\text { Venous }\end{array}$}} & \multirow{2}{*}{\multicolumn{2}{|c|}{$\begin{array}{c}\text { Saturation } \\
\% \text { oxy } \boldsymbol{H b} \\
\text { Venous }\end{array}$}} \\
\hline & & & & \multicolumn{2}{|c|}{ Arterial } & \multicolumn{2}{|c|}{ Venous } & \multicolumn{2}{|c|}{ Arterial } & \multicolumn{2}{|c|}{ Venous } & \multicolumn{2}{|c|}{ Arterial } & \multicolumn{2}{|c|}{ Venous } & \multicolumn{2}{|c|}{ Arterial } & \multicolumn{2}{|c|}{ Venous } & & & & \\
\hline & & & & $\mathbf{B} \ddagger$ & A\& & B & $\mathbf{A}$ & B & $\mathbf{A}$ & B & $\mathbf{A}$ & B & $\mathbf{A}$ & B & $\mathbf{A}$ & B & $\mathbf{A}$ & B & $\mathbf{A}$ & B & $\mathbf{A}$ & B & $\mathbf{A}$ \\
\hline E. $Z$. & $\mathbf{M}$ & 40 & I & $\overline{47.6}$ & 47.9 & $\overline{51.5}$ & 53.2 & 45 & 41 & 50 & 54 & 7.37 & 7.40 & 7.34 & $\overline{7.33}$ & $\overline{17.8}$ & 17.7 & 13.1 & 12.1 & 37 & 34 & 66 & 61 \\
\hline B. S. & $\mathbf{M}$ & 32 & II & 48.9 & 51.6 & 58.0 & 59.5 & 45 & 45 & 60 & 56 & 7.37 & 7.39 & 7.29 & 7.34 & 20.6 & 20.1 & 10.7 & 11.6 & 29 & 30 & 49 & 53 \\
\hline W. P. & $\mathbf{M}$ & 39 & II & 48.6 & 48.7 & 51.6 & 51.2 & 46 & 33 & 54 & 40 & 7.34 & 7.52 & 7.31 & 7.44 & 20.1 & 19.7 & 16.5 & 17.0 & 55 & 53 & 84 & 86 \\
\hline M. M. & $\mathbf{F}$ & 42 & II & 49.4 & 50.5 & 55.0 & 56.1 & 42 & 46 & 54 & 55 & 7.40 & 7.37 & 7.32 & 7.31 & 17.1 & 16.5 & 10.9 & 10.8 & 34 & 35 & 60 & 61 \\
\hline G. G. & $\mathbf{M}$ & 50 & IV & $\overline{51.1}$ & 51.3 & 55.1 & 55.6 & 44 & 39 & 51 & 47 & 7.38 & 7.43 & 7.33 & 7.37 & $\overline{14.1}$ & 14.3 & 9.4 & 8.9 & 37 & 35 & 64 & 62 \\
\hline \multirow{2}{*}{ A. F. } & \multirow{2}{*}{$\mathbf{F}$} & \multirow{2}{*}{50} & \multirow{2}{*}{ IV } & 56.2 & 58.6 & 62.3 & 65.0 & 47 & 50 & 54 & 62 & 7.40 & 7.38 & 7.35 & 7.32 & 15.2 & 14.7 & 8.7 & 7.9 & 32 & 31 & 58 & 54 \\
\hline & & & & 51.0 & 52.9 & 56.3 & \begin{tabular}{|l|}
57.1 \\
\end{tabular} & 45 & 49 & 55 & 54 & 7.35 & 7.36 & 7.29 & 7.31 & 14.8 & 14.7 & 9.0 & 8.4 & 34 & 33 & 58 & 56 \\
\hline S. W. & $\mathbf{M}$ & 47 & IV & 32.5 & 33.0 & 38.6 & 40.2 & 38 & 33 & 45 & 45 & 7.26 & 7.31 & 7.20 & 7.24 & 17.3 & 17.4 & 10.4 & 9.8 & 37 & 33 & 61 & 58 \\
\hline \multirow{2}{*}{ I. B. } & \multirow{2}{*}{$\mathbf{F}$} & \multirow{2}{*}{44} & TV & 40.5 & 41.9 & 47.2 & 48.5 & 31 & 33 & 40 & 41 & 7.44 & 7.43 & 7.38 & 7.37 & 14.9 & \begin{tabular}{|l|}
15.2 \\
\end{tabular} & 8.2 & 8.3 & 27 & 29 & 51 & 53 \\
\hline & & & 10 & $\overline{42.2}$ & 42.3 & \begin{tabular}{|l|}
48.9 \\
\end{tabular} & 49.7 & 37 & 40 & 44 & 49 & 7.37 & 7.34 & 7.32 & 7.28 & 15.5 & 14.9 & 7.9 & 8.2 & 30 & 34 & 52 & 58 \\
\hline T. C. & $\mathbf{M}$ & 43 & IV & $\overline{44.7}$ & 44.1 & 52.8 & 53.0 & 46 & 41 & 48 & 52 & $\overline{7.31}$ & $\overline{7.36}$ & 7.26 & 7.31 & $\overline{19.4}$ & $\overline{19.5}$ & 11.3 & $\overline{11.2}$ & 36 & 34 & 61 & 60 \\
\hline E. D. & $\mathbf{M}$ & 43 & II & $\overline{47.3}$ & 47.3 & 52.2 & 53.0 & 42 & 42 & 52 & 50 & 7.38 & 7.38 & 7.31 & 7.33 & 18.0 & 17.6 & $\mid 12.9$ & 12.2 & 39 & 36 & 68 & 64 \\
\hline
\end{tabular}

TABLE II-Continued

\begin{tabular}{|c|c|c|c|c|c|c|c|c|c|c|c|c|c|c|c|c|c|c|}
\hline \multirow{3}{*}{ Patient } & \multirow{3}{*}{ Sex } & \multirow{3}{*}{ Age } & \multirow{3}{*}{$\begin{array}{l}\text { Smith- } \\
\text { wick } \\
\text { group }\end{array}$} & \multicolumn{10}{|c|}{ Cerebral } & \multirow{2}{*}{\multicolumn{2}{|c|}{$\begin{array}{c}\text { Pulse } \\
\text { rate } \\
\text { per } \\
\text { minute }\end{array}$}} & \multirow{2}{*}{\multicolumn{2}{|c|}{$\begin{array}{c}\text { Respiratory } \\
\text { rate } \\
\text { per } \\
\text { minute }\end{array}$}} & \multirow{3}{*}{$\begin{array}{l}\text { Months } \\
\text { after } \\
\text { adrenal- } \\
\text { ectomy }\end{array}$} \\
\hline & & & & \multicolumn{2}{|c|}{$\begin{array}{l}\text { Blood } \\
\text { flow (X)* }\end{array}$} & \multicolumn{2}{|c|}{$\begin{array}{c}\text { Oxygen } \\
\text { uptake (X) }\end{array}$} & \multicolumn{2}{|c|}{$\begin{array}{l}\text { Vascular } \\
\text { resistancet }\end{array}$} & \multicolumn{2}{|c|}{$\begin{array}{l}\text { Respiratory } \\
\text { quotient }\end{array}$} & \multicolumn{2}{|c|}{$\begin{array}{c}\text { Mean art. } \\
\text { press. } \\
\text { mm. } H_{g}\end{array}$} & & & & & \\
\hline & & & & B & $\mathbf{A}$ & B & $\mathbf{A}$ & B & $\mathbf{A}$ & B & $\mathbf{A}$ & B & $\mathbf{A}$ & B & A & B & A & \\
\hline E. $Z$. & $\mathbf{M}$ & 40 & I & 95 & 70 & 4.5 & 3.7 & $1.3^{T}$ & $1.7^{R}$ & 0.83 & 0.95 & 127 & 115 & 64 & 68 & 12 & 15 & \\
\hline B. S. & $\mathbf{M}$ & 32 & II & 49 & 46 & 4.9 & 3.9 & $2.8^{R}$ & $2.9^{R}$ & 0.92 & 0.93 & 135 & 133 & 66 & 60 & 14 & 12 & \\
\hline W.P. & $\mathbf{M}$ & 39 & II & 32 & 52 & 1.2 & 1.4 & $5.6^{T}$ & $3.2^{\mathrm{R}}$ & 0.83 & 0.93 & 178 & 166 & 87 & 83 & 17 & 17 & \\
\hline M. M. & $\mathbf{F}$ & 42 & II & 80 & 72 & 5.0 & 4.1 & $1.6^{\mathrm{R}}$ & $1.7^{\mathrm{R}}$ & 0.90 & 0.98 & 125 & 123 & 72 & 72 & 24 & 24 & \\
\hline G. G. & $\mathbf{M}$ & 50 & IV & 82 & 67 & 3.9 & 3.6 & $2.0^{R}$ & $2.5^{R}$ & 0.85 & 0.80 & 170 & 170 & 92 & 88 & 24 & 16 & \\
\hline \multirow{2}{*}{ A. F. } & \multirow{2}{*}{ F } & \multirow{2}{*}{50} & \multirow{2}{*}{ IV } & 52 & 52 & 3.4 & 3.5 & 3.4 $^{\mathrm{R}}$ & $3.0^{\mathrm{R}}$ & 0.94 & 1.05 & 175 & 158 & 80 & 64 & 13 & 16 & \\
\hline & & & & 64 & 54 & 3.7 & 3.4 & $1.8^{\mathrm{R}}$ & $2.2^{\mathrm{R}}$ & 0.92 & 0.67 & 116 & 121 & 64 & 60 & 16 & 16 & 12 \\
\hline S. W. & $\mathbf{M}$ & 47 & IV & 49 & 60 & 3.4 & 4.6 & $2.4^{\mathrm{R}}$ & $2.1^{B}$ & 0.88 & 0.94 & 116 & 126 & 72 & 78 & 18 & 22 & 15 \\
\hline \multirow{2}{*}{ I. B. } & \multirow{2}{*}{$\mathbf{F}$} & \multirow{2}{*}{44} & \multirow{2}{*}{ IV } & 44 & 58 & 2.9 & 4.0 & $2.7^{\mathrm{T}}$ & $2.1^{R}$ & 1.00 & 0.96 & 119 & 123 & 80 & 84 & 8 & 8 & 3 \\
\hline & & & & 44 & 50 & 3.3 & 3.4 & $2.6^{R}$ & $2.3^{\mathrm{R}}$ & 0.88 & 1.09 & 116 & 115 & 76 & 78 & 14 & 20 & 12 \\
\hline T. C. & $\mathbf{M}$ & 43 & IV & 72 & 38 & 5.8 & 3.1 & $1.5^{\mathrm{B}}$ & $2.7^{T}$ & 1.01 & 1.07 & 107 & 102 & 78 & 78 & 16 & 16 & 6 \\
\hline E. D. & $\mathbf{M}$ & 43 & II & 86 & 83 & 4.4 & 4.5 & $1.4^{\mathrm{R}}$ & $1.4^{\mathrm{R}}$ & 0.96 & 1.06 & 116 & 116 & 64 & 68 & 12 & 15 & 3 \\
\hline
\end{tabular}

* (X) cc. per 100 grams per minute.

† Cerebral vascular resistance is mean arterial pressure divided by cerebral blood flow expressed as $\mathrm{mm}$. $\mathrm{Hg}$ per cc. blood per 100 grams brain per minute.

B denotes study made before placebo injection.

A denotes study made after placebo injection.

$T$ indicates that the patient appeared tense during the procedure.

$R$ indicates that the patient appeared relaxed during the procedure. 
TABLE III

Mean changes and standard deviation of individual differences in cerebral hemodymamics and oxygen metabolism of patients with essential hypertension after tests with A presoline and placebo

Significant reductions were observed in mean arterial pressure, cerebral vascular resistance and arterial carbon dioxide tension $(p<0.02)$ after "Apresoline." No essential changes were noted after the placebo injection.

\begin{tabular}{|c|c|c|c|c|c|c|c|c|c|c|c|c|}
\hline \multirow{2}{*}{$\begin{array}{l}\text { Patient group } \\
\text { and number of } \\
\text { observations }\end{array}$} & \multicolumn{2}{|c|}{$\begin{array}{c}\text { Mean } \\
\text { arterial } \\
\text { pressure }\end{array}$} & \multicolumn{2}{|c|}{$\begin{array}{c}\text { Cerebral } \\
\text { vascular } \\
\text { resistance }\end{array}$} & \multicolumn{2}{|c|}{$\begin{array}{c}\text { Cerebral } \\
\text { blood } \\
\text { flow }\end{array}$} & \multicolumn{2}{|c|}{$\begin{array}{l}\text { Cerebral } \\
\text { oxygen } \\
\text { uptake }\end{array}$} & \multicolumn{2}{|c|}{$\begin{array}{l}\text { Jugular } \\
\text { oxygen } \\
\text { tension }\end{array}$} & \multicolumn{2}{|c|}{$\begin{array}{l}\text { Arterial } \\
\text { carbon } \\
\text { dioxide } \\
\text { tension }\end{array}$} \\
\hline & B & A & B & $\mathbf{A}$ & B & A & B & $\mathbf{A}$ & B & $\mathbf{A}$ & B & $\mathbf{A}$ \\
\hline \multirow{2}{*}{$\begin{array}{c}\text { Essential } \\
\text { hypertension } \\
\text { with } \\
\text { "Apresoline" } \\
\text { (8) }\end{array}$} & 144 & 113 & 2.8 & 2.1 & 56 & 57 & 3.6 & 3.2 & 36 & 34 & 44 & 38 \\
\hline & $-31^{*} \pm$ & 20 & $-0.7^{*} \pm$ & 0.5 & 1 & 15 & -0.4 & 0.9 & $-2 \pm$ & 3 & $-6^{*} \pm$ & 3 \\
\hline \multirow{2}{*}{$\begin{array}{l}\text { Essential } \\
\text { hypertension } \\
\text { with } \\
\text { placebo } \\
\text { (6) }\end{array}$} & 152 & 144 & 2.8 & 2.5 & 65 & 60 & 3.8 & 3.4 & 37 & 36 & 45 & 42 \\
\hline & $-8 \pm$ & 7 & $-0.3 \pm$ & 1.1 & -5 & 12 & -0.4 & 1.7 & $-1 \pm$ & 2 & $-3 \pm$ & $=6$ \\
\hline \multirow{2}{*}{$\begin{array}{l}\text { After subtotal } \\
\text { adrenalectomy } \\
\text { with } \\
\text { placebo } \\
\text { (6) }\end{array}$} & 115 & 117 & 2.1 & 2.1 & 60 & 57 & 3.9 & 3.8 & 34 & 33 & 40 & 40 \\
\hline & $2 \pm$ & 5 & $0 \pm$ & 0.7 & -3 & 19 & -0.1 & 1.4 & $-1 \pm$ & 3 & $0 \pm$ & $=4$ \\
\hline
\end{tabular}

Units are as in Table $I$.

Signifies statistically significant reduction $(p<0.02)$.

Figures in parentheses denote number of observations in each group.

In each group of patients the figures shown represent in the first line under $B$, the mean values before the injection, and under $A$, the mean values after the injection. In the second line are shown the mean changes with the direction denoted by plus or minus and the mean changes are followed by the standard deviation of the individual differences.

\section{Intramuscular 1-hydrazinophthalazine in pa- tients with essential hypertension}

Mean arterial pressure of this group was reduced from 144 to $113 \mathrm{~mm}$. $\mathrm{Hg}$ approximately 60 minutes after an average dose of $14 \mathrm{mgms}$. (Table III). Cerebral blood flow, oxygen uptake and venous oxygen tension were unchanged. No unpleasant reactions were observed. Pulse rate increased. The data of the individual tests are presented in Table I.

\section{Intravenous saline placebo}

A. In patients with essential hypertension

The data of the individual patients are shown in Table II. Repetition of the observations 60 minutes after the intravenous injection of saline solution showed no significant differences from the initial measurements (Table III). There was no consistent change which could be correlated with the patient's apparent state of nervous tension. Two patients appeared to become more relaxed after the placebo. Vascular resistance in- creased slightly in one (E. Z., Table II) and decreased markedly in the other (W. P., Table II).

B. In patients who had undergone subtotal adrenalectomy alone or combined with sympathectomy

The individual observations are shown in Table II and the mean changes are presented in Table III. There were no significant changes in the cerebral functions measured in these patients one hour after the intravenous saline injection.

One patient (A. F., Table II) was tested with the placebo injection both before and after adrenalectomy-sympathectomy. Minimal changes following the placebo were observed both before and after operation. Cerebral venous oxygen tension in this patient was markedly stable ( 31 to 34 $\mathrm{mm} . \mathrm{Hg}$ ).

I. B. was tested three months and again at twelve months after operation. A slight decrease in resistance was observed after the placebo in each study. This patient was tense during the control cerebral blood flow measurement in the early 
postadrenalectomy study, but not during either the control or the post-injection measurements made twelve months after adrenalectomy. $\mathrm{Re}$ sistance decreased more after the placebo in the earlier study. Although the mean change in cerebral blood flow in this group was small and not significant, one patient, T. C. (Table II), had a reduction of flow almost twice the standard deviation of this group. The arterial carbon dioxide tension of this patient was reduced from 46 to 41 $\mathrm{mm} . \mathrm{Hg}$ as he grew more restless at the end of the 60 minutes. This may account for the reduction in cerebral blood flow (18).

\section{DISCUSSION}

Mean values in Table III indicate that cerebral blood flow was unchanged after "Apresoline" at a time when the arterial carbon dioxide tension was significantly reduced. The 25 per cent reduction in cerebral vascular resistance induced by the drug is all the more impressive because the reduction in arterial carbon dioxide tension would tend to increase cerebral vascular resistance (18). The data of Table III show a tendency for cerebral blood flow to decrease after the saline injection in both groups. This was not observed after 1-hydrazinophthalazine.

Reubi found the renal vascular resistance to be reduced 40 per cent about 45 minutes after an intravenous injection of 10 to 20 mgms. of 1-hydrazinophthalazine (1). The mean arterial pressure of his patients was lower than that of the group we studied, and was reduced by about 15 per cent of the pre-injection level.

Comparative data have been collected on patients with essential hypertension when hypotension in the cerebral arterial system was induced by other drugs $(8,9)$, sympathectomy $(10)$, or twenty degree headup tilt for 20 minutes. The mean reduction in cerebral vascular resistance induced by 1-hydrazinophthalazine appears to be the same (about 25 per cent) as that induced by dihydroergocornine and intravenous protoveratrine.

Reduction in mean cerebral blood flow was observed in patients with essential hypertension only after the extreme pressure drop of differential spinal block. The second flow measurements were made when the arterial pressure appeared to be stabilized, however, and mean oxygen uptake was unchanged. A slight increase in mean oxygen uptake was observed during the head-up tilt. In several of these studies, a reduction in the mean oxygen content of the internal jugular venous blood was observed even though the cerebral oxygen uptake was unchanged $(6,7,10)$.

Such observations raised the question as to whether the mean decreases in cerebral venous oxygen content were associated with significant reductions in jugular venous oxygen tension (6). This uncertainty led us to measure indirectly oxygen tension, thus defining the range of "cerebral oxygen tension" and cerebral blood flow in patients with essential hypertension under the conditions of these experiments.

The relatively close agreement of the measurements in the two groups, as indicated by both mean and individual data, is reassuring when one considers the large number of possible biological, experimental and analytical variations. These observations appear to afford a better baseline for the interpretation of real changes in future studies designed to clarify the influence of varying blood gas tensions on the increased cerebral vascular tone of patients with essential hypertension.

\section{SUM MARY}

Eight measurements of arterial and internal jugular blood gases, cerebral blood flow, oxygen uptake and venous oxygen tension were made in seven patients with mild essential hypertension before and after a reduction in mean arterial pressure induced by intramuscular 1-hydrazinophthalazine ("Apresoline").

The high cerebral vascular resistance of essential hypertension was reduced. This was associated with a slight reduction in arterial carbon dioxide tension. Cerebral blood flow, oxygen uptake and venous oxygen tension were unchanged after the drug.

The data obtained in the "Apresoline" study have been compared with measurements made before and after a placebo injection in six other patients with essential hypertension. Five patients 
who had subtotal adrenalectomy previously were also tested. The observations after the placebo disclosed no significant differences from the initial mean values in each group. Cerebral blood flow and oxygen consumption remained constant.

The reduction in the cerebral vascular resistance of hypertensive patients after "Apresoline" was sufficient to allow cerebral blood flow and oxygen consumption to remain constant and was comparable to that observed during the hypotension induced by dihydroergocornine and protoveratrine.

\section{ACKNOWLEDGMENTS}

The authors are indebted to Drs. Charles W. Crumpton, Walter C. Klingensmith and David P. McCallie for assistance in performing some of the experiments. The aid of Drs. Charles C. Wolferth, William A. Jeffers and Carl F. Schmidt in the preparation of the manuscript is greatly appreciated.

\section{REFERENCES}

1. Reubi, F., Influence de quelques vasodilatateurs périphériques sur le flux sanguin rénal. Helvet. med. acta, 1949, 16, 297.

2. Schmid, A., and Reubi, F., Hämodynamische Eigenschaften zweier neuer Phthalazinderivate. Helvet. med. acta, 1950, 17, 543.

3. Freis, E. D., and Finnerty, F. A., Jr., Suppression of vasomotor reflexes in man following 1-hydrazinophthalazine (C-5968). Proc. Soc. Exp. Biol. \& Med., 1950, 75, 23.

4. Schroeder, H. A., The effect of 1-hydrazinophthalazine in hypertension. Circulation, 1952, 5, 28.

5. Taylor, R. D., Page, I. H., and Corcoran, A. C., A hormonal neurogenic vasopressor mechanism. Arch. Int. Med., 1951, 88, 1.

6. Kety, S. S., King, B. D., Horvath, S. M., Jeffers, W. A., and Hafkenschiel, J. H., The effects of an acute reduction in blood pressure by means of differential spinal sympathetic block on the cerebral circulation of hypertensive patients. J. Clin. Investigation, $1950,29,402$.

7. Hafkenschiel, J. H., Crumpton, C. W., Shenkin, H. A., Moyer, J. H., Zintel, H. A., Wendel, H., and Jeffers, W. A., The effects of twenty degree head-up tilt upon the cerebral circulation of patients with arterial hypertension before and after sympathectomy. J. Clin. Investigation, 1951, 30, 793.
8. Hafkenschiel, J. H., Crumpton, C. W., Moyer, J. H., and Jeffers, W. A., The effects of dihydroergocornine on the cerebral circulation of patients with essential hypertension. J. Clin. Investigation, 1950, 29, 408.

9. Crumpton, C. W., Klingensmith, W. C., Keffer, N. J., and Hafkenschiel, J. H., Effects of protoveratrine on cerebral hemodynamics and oxygen metabolism in hypertensive subjects. Federation Proc., 1951, 10, 32.

10. Shenkin, H. A., Hafkenschiel, J. H., and Kety, S. S., Effects of sympathectomy on the cerebral circulation of hypertensive patients. Arch. Surg., 1950, $61,319$.

11. Smithwick, R. H., The effect of sympathectomy upon the mortality and survival rates of patients with hypertensive cardiovascular disease. Bell, E. T., Ed., Hypertension. A symposium held at the University of Minnesota on September 18, 19, and 20, 1950, in honor of E. T. Bell, B. J. Clawson and G. E. Fahr. University of Minnesota Press, Minneapolis, 1951 , p. 429.

12. Hafkenschiel, J. H., Friedland, C. K., and Crumpton, C. W., Subtotal adrenalectomy in essential hypertension : preliminary report of the effects on cerebral hemodynamics and oxygen metabolism. Am. J. Physiol., 1951, 167, 790.

13. Kety, S. S., and Schmidt, C. F., The nitrous oxide method for the quantitative determination of cerebral blood flow in man: Theory, procedure and normal values. J. Clin. Investigation, 1948, 27, 476.

14. Kety, S. S., Hafkenschiel, J. H., Jeffers, W. A., Leopold, I. H., and Shenkin, H. A., The blood flow, vascular resistance, and oxygen consumption of the brain in essential hypertension. J. Clin. Investigation, 1948, 27, 511.

15. Rosenthal, T. B., The effect of temperature on $\mathrm{pH}$ of blood and plasma in vitro. J. Biol. Chem., 1948, 173, 25.

16. Handbook of respiratory data in aviation. Committee on Medical Research, Office of Scientific Research and Development, Washington, D. C., 1944, Section B, Chart B-1, a and b.

17. Scheinberg, P., Cerebral blood flow in vascular disease of the brain. With observations on the effects of stellate ganglion block. Am. J. Med., 1950, $8,139$.

18. Kety, S. S., and Schmidt, C. F., The effects of active and passive hyperventilation on cerebral blood flow, cerebral oxygen consumption, cardiac output, and blood pressure of normal young men. J. Clin. Investigation, 1946, 25, 107. 